\title{
MORPHOMETRIC ANALYSIS OF FORAMEN MAGNUM IN ADULT HUMAN DRY SKULL OF GUJARAT REGION
}

Bharat.J.Sarvaiya ${ }^{1}$, Shital.Bhishma. Hathila ${ }^{* 2}$, Jagdish.S.Chaudhari ${ }^{3}$, Nilesh.C.Fichadiya ${ }^{4}$.

${ }^{1}$ M.S.Anatomy, Associate Professor, Anatomy Department, P.D.U.Govt.Medical College, Rajkot, Gujarat, India.

${ }^{* 2}$ Assistant Professor, Anatomy Department, Medical College, Baroda, Gujarat, India.

${ }^{3}$ Associate Professor, Anatomy Department, Government Medical College, Bhavnagar, Gujarat, India.

${ }^{4}$ Tutor, PSM Department, P.D.U.Govt. Medical College, Rajkot, Gujarat, India.

\section{ABSTRACT}

Background: Morphometric analysis of the foramen magnum of dry human skulls in Gujarat region was carried out to demonstrate the anatomical variations in morphology. The measurements of the foramen magnum are clinically important because vital structures passing through it. There are certain diseases associated with compression of structure present in foramen magnum like arnold chiari malformation (tonsillar herniation), achondroplasia, stenosis of foramen magnum, meningioma and atlanto-occipital fusion.

Objectives: The aim of this study was to measure anteroposterior \& transverse diameter of foramen magnum, surface area and index of foramen magnum and to observe its various shapes.

Materials and methods: 326 dry skulls of adult human being were studied. Antero-posterior and Transverse Diameter were measured by using a digital vernier caliper. The surface area and foramen magnum index were calculated. The cranial base was visually assessed for the shape of foramen magnum.

Results: The mean antero-posterior and transverse diameter of the foramen magnum were $34.18 \pm 2.74 \mathrm{~mm}$ and $28.49 \pm 2.13 \mathrm{~mm}$ respectively. The mean surface area and the foramen magnum index were $766.86 \pm 104.76 \mathrm{~mm}^{2}$ and $83.60 \pm 6.21 \mathrm{~mm}$ respectively. The percentages of different shapes of foramen magnum were: Oval (42.33\%), Round (32.82\%), Tetragonal (8.59\%), Hexagonal (7.67\%), Pentagonal (4.60\%), and irregular (3.99\%).

Conclusion: The knowledge of various dimensions \& shape of the foramen magnum help to determine some malformations like arnold chiari syndrome in which the transverse diameter is increased. The antero-posterior diameter of foramen magnum was more than the transverse diameter and most common shape of foramen magnum was found to be Oval.

KEY WORDS: Skull, Morphometry, Foramen Magnum, Antero-Posterior diameter, Transverse diameter.

Address for Correspondence: Dr. Shital.Bhishma. Hathila, A-13,Darshanam Villa-2, Near Sapphire School, Near Savita Hospital, Parivar cross road, Waghodia Road, Baroda, Gujarat, India. Mobile: 9825121336 E-Mail: bhishushital@gmail.com

Access this Article online

Quick Response code

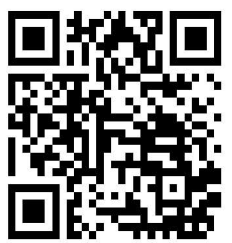

DOI: $10.16965 /$ ijar.2018.345

Journal Information

International Journal of Anatomy and Research

ICV for 2016 ISSN (E) 2321-4287 | ISSN (P) 2321-8967

90.30 https://www.ijmhr.org/ijar.htm DOI-Prefix: https://dx.doi.org/10.16965/ijar

\section{Article Information}

Received: 04 Aug 2018

Peer Review: 06 Aug 2018

Revised: None
Accepted: 06 Sep 2018

Published (O): 10 Oct 2018

Published (P): 10 Oct 2018
INTRODUCTION

The neurocranium consist of cartilaginous portion that forms base of skull. Base of occipital bone including boundaries of foramen 
magnum which is formed by the parachordal plate and cartilage derived from four occipital somites (sclerotome) [1]. The foramen magnum is large oval aperture of the occipital bone, wider behind then in front, as its anterolateral margin was encroached by occipital condyle and it communicate the posterior cranial fossa with the vertebral canal. It measured about $3.5 \mathrm{~cm}$ anteroposteriorly \& $3 \mathrm{~cm}$ transversely [2]. Foramen magnum is a latin word meaning largest aperture in the base of skull. It is situated in an anteromedian position. It contains the lower end of medulla oblongata \& meninges surrounding it, cerebrospinal fluid, vertebral arteries and veins, spinal part of accessory nerve. In its anterior part apical ligament of dens, upper vertical bend of cruciate ligament and tectorial membrane pass through it to attached internal basiocciput [3].

The Arnold-Chiari malformation is a congenital anomaly in which there is a herniation of the tonsils of the cerebellum and the medulla oblongata through the foramen magnum into the vertebral canal which shows increased transverse diameter of foramen magnum [4, 5].Enlargement of foramen magnum occur mostly in patients with Chiari-I \& II type of malformation as compared to normal population [6]. Growth failure of cranial base as a result of abnormal cartilaginous bone growth and premature fusion of bone by synchondrosis result in small foramen magnum that occurs in group of bone dysplasia including achondroplasia and stenosis. Stenosis of foramen magnum is mostly associated with achondroplasia in which the opening is not large enough to pass the spinal cord easily [7, 32].

The skull with largest anteroposterior diameter permit greater contralateral surgical exposure for condylar resection in transcondylar approach and also help to access the lesion locate at cervicome-dullary junction \& ventral to brainstem [8].

Morphometric analysis of foramen magnum conducted in this study is important and useful not only for anatomist, but also important for Anthropologist, Forensic expert, Neurosurgeons, Radiologist, Anesthetist and Physicians to diagnose and treat various deformities associated with foramen magnum.

\section{MATERIALS AND METHODS}

With prior permission taken from head of anatomy department of various medical colleges of Gujarat including anatomy department P.D.U. Govt, Medical College, Rajkot (Gujarat) we have conducted the study on completely ossified 326 dry adult human skulls of unknown age and sex for analysis. The skulls were accepted as adults according to tooth eruption. Any skulls showed signs of prior cranial surgery, malformation, damaged, incomplete, with any pathological condition and juvenile skull were excluded. In this study we have measured the anteroposterior diameter (APD) \& transverse diameter (TD) of foramen magnum by using digital vernier caliper with an accuracy of $0.01 \mathrm{~mm}$. The measurements was taken with due care to ensure accurate measurement. APD of foramen magnum is the distance between opisthion to basion along midsagittal plane and TD is the maximum distance between lateral margins of foramen magnum as shown in (Figure-1). The opisthion is the central point of the posterior edge of foramen magnum and the basion is central point of the anterior edge of foramen magnum [9]. The surface area of foramen magnum was calculated by Length (APD) \& Width (TD) of foramen magnum by using formula given by Radinsky $(1 / 4 \times W \times L \times \pi)$ where $\pi=22 / 7$, mathematical constant [10]. $\pi$ was accepted as 3.14. The foramen magnum index was calculated by using formula (TD $\times 100 / A P D$ ) [11]. The cranial base was macroscopically assessed for different shape of foramen magnum and noted as oval, round, tetragonal, pentagonal, hexagonal \& irregular. The statistical analysis was done using Epi Info software ver. 7.2.2.1.

\section{OBSERVATIONS}

APD, TD, surface area and index of foramen magnum were taken, analyzed and recorded on total 326 dry skulls. The mean APD of the foramen magnum was $34.18 \pm 2.74 \mathrm{~mm}$ with range from $26.68-44.06 \mathrm{~mm}$. The mean TD of the foramen magnum was $28.49 \pm 2.13 \mathrm{~mm}$ with range from $23.30-35.75 \mathrm{~mm}$. The mean surface area of foramen magnum was $766.86 \pm$ $104.76 \mathrm{~mm}^{2}$ with range from $508.10-1124.67$ $\mathrm{mm}^{2}$. The mean foramen magnum index was 
Table 1: Showing comparison of APD, TD, and Surface Area \& Index of foramen magnum.

\begin{tabular}{|c|c|c|c|c|c|c|}
\hline Author & Population & \begin{tabular}{|c|} 
Sample size \\
(N)
\end{tabular} & APD (mm) & TD (mm) & Mean Area $\left(\mathrm{mm}^{2}\right)$ & F M Index \\
\hline Present & Gujarat & 326 & $34.18 \pm 2.74$ & $28.49 \pm 2.13$ & $766.86 \pm 104.76$ & $83.60 \pm 6.21$ \\
\hline Raj Kumar [12] & North India & 298 & $33.98 \pm 2.75$ & $28.16 \pm 2.12$ & $754.32 \pm 105.60$ & $83.14 \pm 6.33$ \\
\hline Abhinav M [13] & UP & 71 & $34.09 \pm 2.23$ & $28.22 \pm 2.19$ & ------- & ----- \\
\hline K.C.Singh [14] & Varanasi & 50 & $33.76 \pm 2.18$ & $28.09 \pm 1.92$ & $834.85 \pm 75.79$ & $84.65 \pm 6.32$ \\
\hline Lucas A S [15] & Brazilian & 77 & $34.23 \pm 2.54$ & $28.62 \pm 2.83$ & $772.4 \pm 116.7$ & $83.75 \pm 7.23$ \\
\hline Sampada P K [16] & Karnataka & 100 & $34.84 \pm 2.32$ & $29.39 \pm 1.73$ & $803.8 \pm 83.42$ & N.A \\
\hline Remya K [17] & Mangalore & 50 & $33.64 \pm 2.28$ & $27.04 \pm 2.14$ & $714.99 \pm 84.40$ & N.A \\
\hline Radhika P M [18] & Banglore & 150 & $35.30 \pm 2.7$ & $29.49 \pm 2.6$ & NA & NA \\
\hline Deepa G [19] & Karnataka & 100 & $34.1 \pm 3.36$ & $28.68 \pm 2.93$ & 774.17 & 84.18 \\
\hline Patel R [20] & Surat Gujarat & 100 & 33.7 & 28.29 & 755.37 & N.A \\
\hline Dr.P C Jain [21] & Central India & 100 & 33.5 & 27.1 & 748 & N.A \\
\hline Kizikanat [22] & Turkey & 59 & $34.8 \pm 2.2$ & $29.6 \pm 2.4$ & N.A -- & N.A \\
\hline Avci et al [23] & Turkey & 30 & 34.5 & 29 & N.A -- & N.A \\
\hline Sanjukta S [24] & India & 150 & $35.3 \pm 2.7$ & $29.49 \pm 2.57$ & N.A -- & N.A \\
\hline Sayee R [25] & Karnataka & 350 & 34.2 & 27.2 & 769 & N.A \\
\hline N Muthukumar [8] & Madurai & 50 & 33.3 & 27.9 & NA & N.A \\
\hline Berge \& Bergmann[26] & USA & 100 & 33.8 & 28.3 & $\mathrm{NA}$ & N.A \\
\hline Routal et al [27] & Gujarat & --- & 35.5 & 30.1 & 819 & N.A \\
\hline Shikha Sharma [28] & UP-Indian & 50 & 38.75 & 33.44 & 970.57 & 87.68 \\
\hline Govsa et al [29] & Turkey & 144 & $37.2 \pm 3.5$ & $30.8 \pm 2.9$ & $829 \pm 137.7$ & N.A \\
\hline Akay et al [30] & Turkey & 190 & $\begin{array}{c}M-36.43 \pm 2.32 \\
F-34.66 \pm 2.31\end{array}$ & $\begin{array}{c}\text { M- } 31.26 \pm 2.41 \\
\text { F- } 29.78 \pm 2.05\end{array}$ & N.A & N.A \\
\hline Wanebo J E [31] & USA & 32 & $36.0 \pm 3.0$ & $31.0 \pm 2$ & $780 \pm 110$ & N.A \\
\hline Osunwoke E A [32] & Nigeria & 50 & $36.11 \pm 2.60$ & $29.56 \pm 2.60$ & N.A & N.A \\
\hline Faazila Fathima [33] & Chennai & 53 & 38.22 & 35.15 & 1102.5 & N.A \\
\hline Manole C et al [34] & Brazilian & 215 & $\begin{array}{c}M-35.7 \pm 2.9 \\
F-35.1 \pm 3.3\end{array}$ & $\begin{array}{l}M-30.0 \pm 2.0 \\
\text { F- } 29.4 \pm 2.3\end{array}$ & NA & N.A \\
\hline Gruber et al [35] & ---- & & 36.5 & 31.1 & 909 & N.A \\
\hline Berjina N [36] & Kashmir & 25 & $31.6 \pm 2.16$ & $26.50 \pm 2.12$ & $660.00 \pm 90.00$ & $83.64 \pm 5.71$ \\
\hline Chethan P [37] & India & 53 & $31 \pm 2.4$ & $25 \pm 2.4$ & N.A & N.A \\
\hline Tubb R S [38] & Birmingham & 72 & 31 & 27 & 558 & N.A \\
\hline
\end{tabular}

Table 2: Showing comparison of percentage of different shapes of foramen magnum.

\begin{tabular}{|c|c|c|c|c|c|c|c|c|}
\hline Shape of F.M in \% & Sample & Oval & Round & Egg & Tetragonal & Pentagonal & Hexagonal & Irregular \\
\hline Present study & 326 & 42.33 & 32.82 & --- & 8.59 & 4.6 & 7.67 & 3.99 \\
\hline Rajkumar [12] & 298 & 66 & 24.83 & --- & 3.35 & 2.68 & 4.02 & --- \\
\hline Abhinav M [13] & 71 & 33.8 & 30.98 & & 7.04 & 7.04 & 11.26 & 9.85 \\
\hline K C Singh [14] & 50 & 34 & 20 & --- & 16 & 4 & 18 & 8 \\
\hline Lucas A S [15] & 77 & 53.24 & 24.67 & 2.36 & 16.88 & 1.29 & --- & 1.29 \\
\hline Sampada P K [16] & 100 & 58 & 9 & 11 & 8 & 1 & 3 & 10 \\
\hline Remya K et al [17] & 50 & 46 & 16 & 14 & 20 & --- & 2 & 2 \\
\hline Fathima et al [33] & 53 & 26.42 & 13 & 35.85 & --- & 3.77 & 20.75 & --- \\
\hline Radhakrushna [39] & 100 & 39 & 28 & --- & 19 & 14 & --- & -- \\
\hline Gopalkrishna [40] & 55 & 41 & 25 & --- & 14 & --- & --- & 20 \\
\hline Ganapathy A [41] & 100 & 42 & 9 & --- & 17 & --- & 9 & 22 \\
\hline Radhika P M [18] & 150 & 40 & 20 & 10 & 6 & 2 & 6 & 16 \\
\hline Anilkumar [42] & 36 & 50 & 20 & --- & 6 & --- & 8 & 16 \\
\hline Rathva A [43] & 210 & 28.75 & 16.66 & 11.9 & 10.47 & 2.38 & 4.76 & 15.71 \\
\hline N Muthukumar[8] & 50 & 46 & 54 & --- & --- & --- & --- & --- \\
\hline Shikha S [28] & 50 & 16 & 22 & 16 & 12 & 8 & 8 & 18 \\
\hline Akay et al [30] & 190 & 12.6 & 21.6 & 6.8 & 7.9 & 9.5 & 18.4 & 23.2 \\
\hline Chethan P [37] & 53 & 15.1 & 22.6 & 18.9 & 18.9 & 3.8 & 5.6 & 15.1 \\
\hline Ravendranath [44] & 100 & 6 & 15 & 12 & 11 & 3 & 21 & 32 \\
\hline
\end{tabular}


$83.60 \pm 6.21 \mathrm{~mm}$ with range from $67.70-110.97$ $\mathrm{mm}$ (Table-1). The various shape of foramen magnum (Figure-2) was recorded and noted in decreasing frequency - Oval $(42.33 \%)$, Round (32.82\%), Tetragonal (8.59\%), Hexagonal (7.67\%), Pentagonal (4.60\%), and irregular (3.99\%) (Table-2, Figure-3). In present study of 326 skull, we have found only one skull with foramen magnum having anteroposterior diameter smaller $(31.37 \mathrm{~mm})$ than the transverse diameter (34.81 mm) (Figure- 4).

Fig. 1: The anteroposterior and transverse diameter of foramen magnum.

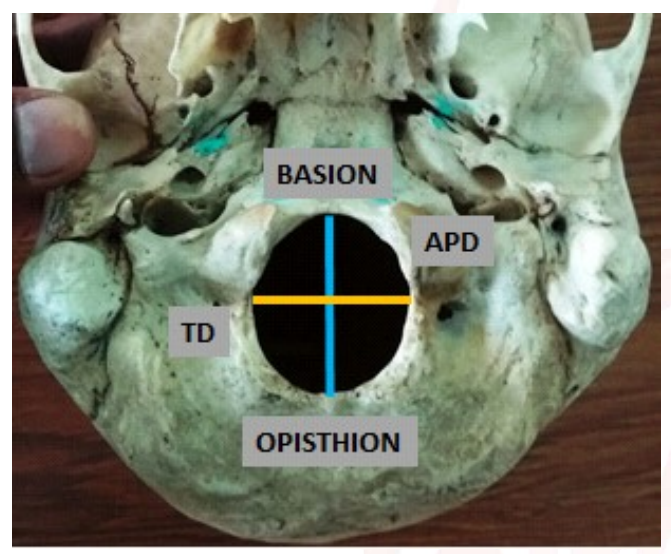

Fig. 2: Various shapes of foramen magnum.
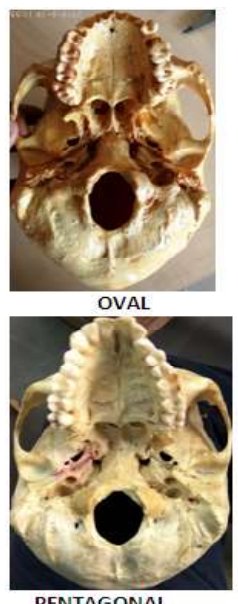
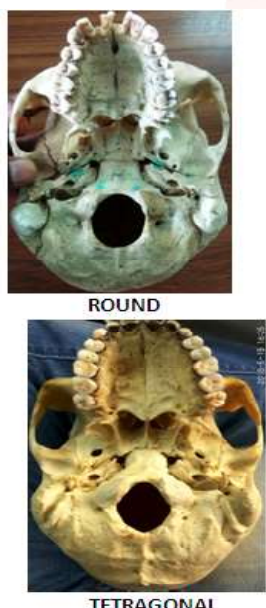

TETRAGONAL
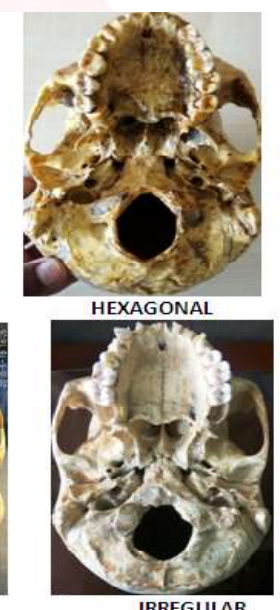

Fig. 3: Percentages of various shape of FM in present study.

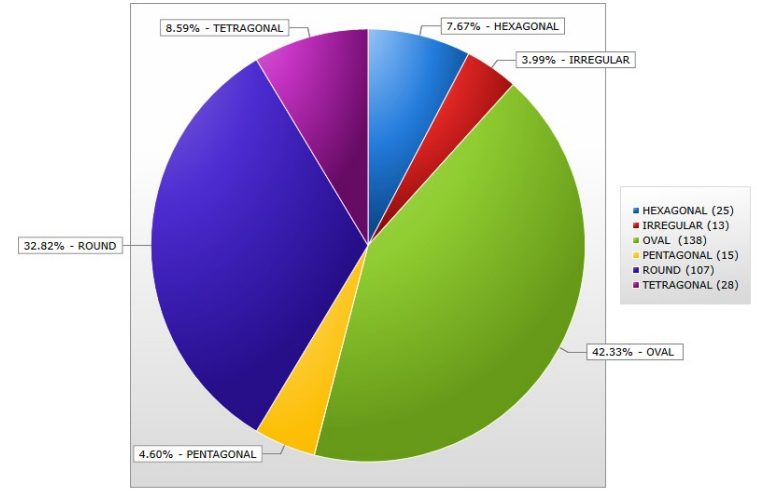

Fig. 4: FM with Large TD then APD.

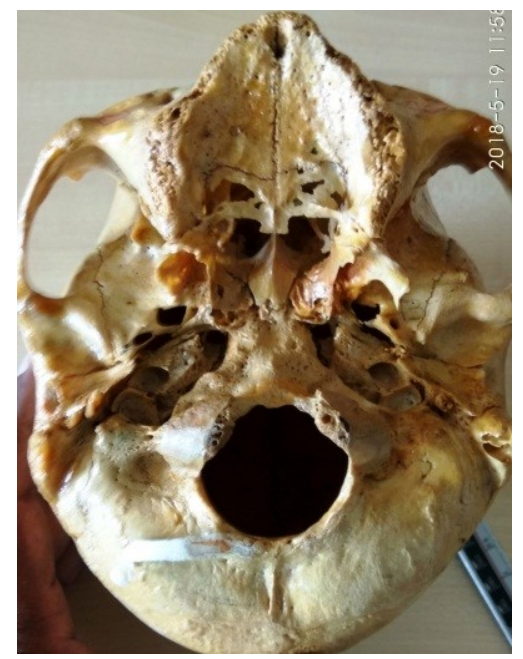

\section{DISCUSSION}

In present study, the mean APD of foramen magnum was $34.18 \pm 2.74 \mathrm{~mm}$ with range from $26.68 \mathrm{~mm}$ to $44.06 \mathrm{~mm}$. Mean TD of foramen magnum was $28.49 \pm 2.13 \mathrm{~mm}$ with range from $23.30 \mathrm{~mm}$ to $35.75 \mathrm{~mm}$. Various authors have studied the morphometric features of foramen magnum from different parts of India and world. The comparison of APD and TD of the present study with the study done by other authors are shown in Table-1. Our findings are similar to the findings of N Muthukumar [8], Rajkumar [12], Abhinavkumar Mishra [13], K C Singh [14], Lucas A S Pires [15], Sampada P K [16], Remya K [17], Radhika P M [18], Deepa G [19], Patel Roma [20], Jain P C [21], Kizikanat [22], Avci [23], Sanjukta S [24], Sayee R [25], Berge \& Bergman [26], Routal et al [27]. Our finding was lower than the findings of Shikha sharma [28], Govsa [29], Akay [30], Wanebo \& Chicoine [31], Osunwok E A [32], Faazila Fathima [33], Manole $C$ et al [34], Gruber P [35]. Our findings of APD $\&$ TD were higher than the findings of Berjina $F$ [36], Chethan P [37] and Tubb R S [38].

The mean surface area of foramen magnum was $766.86 \pm 104.76 \mathrm{~mm}^{2}$, with range from 508.10 to $1124.67 \mathrm{~mm}^{2}$. In this study, our findings of mean area of FM are similar to the findings of Rajkumar [12], K C Singh [14], Lucas A S [15], Sampada P K [16], Remya K [17], Deepa G [19], Patel Roma [20], Jain P C [21], Sayee R [25], Routal et al [27]. The mean area of FM was reported higher by Shikha Sharma [28], Govsa [29], Faazila Fathima [33], Gruber P [35] as compared to our study. 
The mean foramen magnum index in present study was $83.60 \pm 6.21 \mathrm{~mm}$, with range from 67.70 to 110.97 (Table-1). This findings are similar to finding of Rajkumar [12], K.C.Singh[14], Lucas A S [15], Deepa G [19], Berjina farooq naqshi [36]. The study done by Shikha $S$ [28] reported $\mathrm{FMI}$ is 87.68 which is higher than our study.

The Shape of foramen magnum in present study was compared with other authors showing (Table -2). The most common shapes of the foramen magnum is oval in present study and it is similar with Rajkumar [12], Abhinav Kumar M [13], K C Singh [14], Lucas A S [15], Sampada P K [16],Remya K [17], Radhika P M [18], Faazila Fathima [33], Radhakrushna [39], Gopalkrishna [40], Ganapathy A [41], Anilkumar [42], Rathva A [43]. The study done by N Muthukumar [8], Shikha S [28], Akay [30], Chethan P [37], Raveendranath [44], have reported that the common shape of foramen magnum is round. The data obtained from the present study was compared with the data reported by other authors. After the comparison, we observed that our findings like APD, TD, surface area, FM index and percentages of various shapes of foramen magnum are almost similar.

\section{CONCLUSION}

The foramen magnum is formed by four parts, viz basilar, right \& left condylar and squamous part of occipital bone; there are so many variations in its dimension and shape. The study of morphometric analysis of FM is important as there are many neurovascular structures passing through it and they may get compressed in various deformities at craniovertebral junction like CM-1 \& CM-2, achondroplasia, stenosis of FM, meningioma's, foramen magnum syndrome, etc. This study is helpful in the field of anatomy, forensic medicine, anthropology and has great clinical significance in neurosurgery, radiology, orthopedics and anesthesia to determine treatment plan in case of foramen magnum decompression surgery (Craniectomy with Laminectomy of Atlas vertebra) for chiary malformation and craniovertebral \& cervical spine surgery.

\section{ACKNOWLEDGEMENTS}

The authors are heartily thankful to all the respected head of department of anatomy of various medical colleges of Gujarat for allowing us to do study in their respective department. We are also thankful to all faculties and supporting staff of all anatomy departments they help us in this study.

\section{ABBREVIATION}

APD- Anteropoosterior diameter

TD- Transverse diameter

FM- Foramen magnum

CM- Chiary malformation

MM- Millimeter

\section{Conflicts of Interests: None}

\section{REFERENCES}

[1]. Vishram Singh, Textbook of clinical embryology; Elsevier India; 2015, 1e, p93.

[2]. Datta A.K, Essentials of human anatomy, Head \& Neck; Current books international, Kolkata India; $20074^{\text {th }}$ ed, p56.

[3]. Standring S,Gray's Anatomy:The anatomical basis of clinical practice. elsevier, churchil livingstone, Edingerg; 2016, 41 ${ }^{\text {st }}$ ed, p 422.

[4]. Snell, Richard S. "Clinical Neuroanatomy, Lippincott williams \& wilkins,Philadelphia; 2010" $7^{\text {th }} \mathrm{ed} \mathrm{,}$ p.195.

[5]. Sgouros S, Goldin HJ, Hockely AD, Wake MJ, et al. Intracranial volume change in childhood. J Neurosurge.1999;610-616.

[6]. Gardner WJ, Goodall RJ. The surgical management of Arnold-Chiari malformation in adults.An explanation of its mechanism and importance of encephalography in diagnosis. J neurosurg 1950;7:199-206.

[7]. Hecht TJ, Horton WA, Reid CS, et al. Growth of the foramen magnum in achondroplasia. American Journal of Medical Genetics.1989;32:528-35.

[8]. Muthukumar N, Swami Nathan R, Venkatesh G, Bhanumathy SP. A morphometric analysis of the foramen magnum region as it relates to thetranscondylar approach. ActaNeurochir (Wien).2005;147(8):889-95.

[9]. Breathnach A.S, Frazer's Anatomy of the human skeleton, 6th edition, 1960; p-179.

[10]. Radinsky L. Relative brain size a new measure. Science 1967;155:836-838.

[11]. Martin R. Saller K. Lehrbuch de Anthropologie. Band 1.Stuttgart: Gustov Fisher Verlag, 1957; 455-509.

[12]. Rajkumar, Prabhakaran k, Punita Manik,Vikram Singh, morphometric analysis of the foramen magnum of dry human skulls in north indian population, Int J Anat Res 2017;5(1):3480-84.ISSN 232142873480.

[13]. Abhinavkumar Mishra, shashi bhushan pandey, chandan kumar yadav, mahboobul haque, naresh Chandra, Morphometric study of foramen magnum of skull in poplation in Uttar Pradesh.Int $\mathrm{J}$ anat Res 2018,6(2.2):5186-90. 
[14]. K.C.Singh,Gunjan Rai, Rahul Rai,Morphological Variations of the Foramen Magnum in adult Human Dry Skull in Eastern UP(India)Population Int J Med Res Prof. 2017;3(2): 205- 8.

[15]. Lucas A.S.Pires, Álvaro R. Teixeira, Tulio F. O. Leite, Marcio A. Babinski and Carlos A. A.Chagas, Morphometric aspects of the foramen magnum and the orbit in Brazilian dry skulls Int J Med Res Health Sci. 2016;5(4):34-42.

[16]. Sampada p k, Poornima b, Mallikarjun m, Santosh b sakri, Morphometric and Morphological study of foramen magnum in dried human skull bones. Int J Anat Res 2017;5(2.1):3682-86.

[17]. Remya K,Pretty Rathnakar ,Swathi evaluation of foramen magnum in dry human skulls of dakshina kannada district, Int J Anat Res 2017;5(4.1):448891.

[18]. Radhika P.M,Shailaja Shetty,Prathap K.J,C.Sheshgiri, Jyothi K.C,Morphometric study of foramen magnum in adult human skull in indian population, Asian $\mathrm{j}$ of med clin sci.2014;3(2).

[19]. Deepa G,Shrikrishan B.H, Morphometric analysis of foramen magnum in dry adult human skull,Indian journal of anatomy, 2016;5(3).

[20]. Patel R, Mehta CD. Morphometric study of Foramen Magnum at the base of human skull in South Gujarat.IOSR Journal of Dental and Medical Sciences. 2014;13(6), Ver.IV:23-25.

[21]. Jain PC, Tiwari N, Gour KK. Morphometric analysis of foramen magnum in human dry skulls in Central India Region. Indian Journal of Research. 2017;6(2):18-20.

[22]. Kizilkanat ED, Boyan N, Soames R, Oguz. Mrphometry of the hypoglossal canal, occipital condyle and foramen magnum. Neurosurg Quarter James Cook Univ 2006;16:121-5.

[23]. Avci E, Dagtekin A, Ozturk AH, Kara E, Ozturk NC,Uluc $\mathrm{K}$, et al. Anatomical variations of the foramen magnum, occipital condyle and jugular tubercle. Turk Neurosurg 2011;21:181-90.

[24]. Sanjukta Sahoo, Sanjay Kumar Giri et al morphometric Analysis of the foramen magnum and occipital condyles. Int.J.Pharma.Sci.Rev.Res. 2015;33(2):198-204.

[25]. Sayee R, Janakiram S, Thomas IM. Foramen magnum measurements of Crania from Karnataka. Journal of Anatomical Society of India. 1987;36:87-89.

[26]. Berge JK, Bergman RA. Variations in size and in symmetry of foramina of the human skull. Clin Anat 2001;14:406.

[27]. Routal RR, Pal GP, Bhagwat SS, Tamankar BP. Material studies with sexual dimorphism in foramen magnum of human crania. Journal Anat. Soc. Of India 1984;33(2):85-89

[28].Shikha Sharma, Anil Kumar Sharma, Bhawani Shankar Modi, Mohd. Arshad. morphometric evaluation of the foramen magnum and variation in its shape and size: a study on human dried skull. Int J Anat Res 2015;3(3):1399-03. ISSN 2321- 4287.

[29]. Govsa F, Ozer MA, Celik S, Ozmutaf NM. Three-dimensional anatomic landmarks of the foramen magnum for the craniovertebral junction.J Craniofac Surg 2011;22:1073-6.
[30]. Gulsun AKAY,Kahraman GUNGOR,Ilkay PEKER, Morphometric analysis of foramen magnum by using cone beam tomography,Turk J Med Sci 2017;47:17151722.

[31]. Wanebo J.E, Chicoine M.R. Quantitative analysis of the transcondylar approach to the foramen magnum.Neurosurgery 2001;49:934-41. (discussion 941-3).

[32]. Osunwoke EA, Oladipo GS, Gwunireame IU, Ngaokere JO,2012; Morphometric analysis of the foramen magnum and jugular foramen in adult skull in southern Nigerian population. Am J Sci Ind Res 2012;3:446-8.

[33]. Faazila fathima,K.yuvaraj babu,Evaluating the shape of foramen magnum and overlapping of occipital coindyle on the foramen.Int J Sci Res. 2016;5(9):1078-82.

[34]. Manoel C, Prado FB, Caria PHF, Groppo FC. Morphometric analysis of the foramen magnum in human skulls of brazilian individuals: its relation to gender.Braz. J. Morphol.Sci 2009;26(2):104-108.

[35]. Gruber P,Henneberg M, Boni T,Ruhli F.J. variability of foramen magnum size. Anat Rec: 2009;292:171319

[36]. Berjina farooq, naqshi, Shaheen shahdad,Nida kawoosa, Adil bashir shah. morphological and morphometric study of foramen magnum in dry human skulls of kashmir gjra - global journal for research analysis 2017;6(8):1-3.

[37]. Chethan P, Prakash KG, Murlimanju BV, PrashanthKU,Prabhu LV, Saralaya W. et al. Morphological analysis and morphometry of the foramen magnum: an anatomical investigation. Turk Neurosurg. 2012;22:416-9.

[38]. Tubbs RS, Griessenauer CJ, Loukas M, Shoja MM, Cohen-Gadol AA. Morphometric analysis of the foramen magnum: an anatomic study. Neurosurgery 2010;66:385-8.

[39]. Radhakrishna S.K, Shivarama C.H,Ramkrishna A,Bhagya B,Morphometric analysis of foramen magnum for sex determination in south indian population, NUJHS 2012;2(1):20-22.

[40]. Dr.Gopalkrishna K, Dr.B.S.Rathna,The craniometric analysis of foramen magnum of Indian population and variation in its dimention, IJAMSCR, 2001;3(2):205-211.

[41]. Ganapathy Arthi, Sadeesh T, Sudha Rao, Morphometric analysis of foramen magnum in adult human skull and CT image, Int JCur Res rev, 2014;6(20):11-15.

[42]. Anil Kumar, Mitesh Dave, Sanam Anwar. Morphometric Evaluation of Foramen Magnum in Dry Human Skulls. Int J Anat Res 2015;3(2):1015-23.

[43]. Ajay R, Kalindi S, Bhavika P,Ojaswini M, Morphometry and sexual dimorphism of human skull foramen magnum, Int $J$ Rec trend sci tech 2015;15(2):379-386.

[44]. Raveendranath V, Manjunath K.Y, Umamageshwari amirathlingam,Morphological and morphometric study of variation in shape and size of foramen magnum of human skull. Int j Ana Rad and Surgery, 2018;7(2):A001-A0008. 